Para enlazar con este artículo / To link to this article:

http://dx.doi.org/10.14198/fem.2019.34.11

Para citar este artículo / To cite this article:

Beltrán, Cristina. «Representación del cuerpo, el género y la "raza" en Vida y muerte de la mulata. Una historia que se repite». En Feminismo/s, 34 (diciembre 2019): 235-263. DOI: 10.14198/fem.2019.34.11

\title{
REPRESENTACIÓN DEL CUERPO, EL GÉNERO Y LA «RAZA» EN VIDA Y MUERTE DE LA MULATA. UNA HISTORIA QUE SE REPITE
}

\author{
BODY REPRESENTATION, «RACE» AND GENDER IN VIDA \\ Y MUERTE DE LA MULATA. A STORY THAT REPEATS ITSELF
}

\author{
CRISTINA BELTRÁN \\ Universidad de Barcelona, Barcelona \\ crisbf1404@gmail.com \\ https://orcid.org/0000-0001-5151-6179
}

\begin{abstract}
Resumen
El presente artículo versa sobre la construcción del estereotipo de «la mulata» en las narrativas hegemónicas de la literatura, el arte y la ciencia cubana en la segunda mitad del siglo XIX. Me interesa abordar qué imágenes y ausencias han ido creando esta representación y, más que su significado, qué se buscaba con ellas. Utilizo las claves interpretativas propuestas en la perspectiva del feminismo interseccional y una metodología interdisciplinar aplicada al estudio de esta representación del racismo sexualizado. Planteo que «la mulata» decimonónica fue una construcción de alteridad que permitió la continuación de los imaginarios coloniales de «raza», de género y de clase -funcionales al ordenamiento social- y, como artefacto, (re)significó la cosificación del cuerpo negro, enmascarando la violencia hacia las mujeres afrodescendientes cubanas.
\end{abstract}

Palabras clave: mulata; estereotipos; raza; género; racismo sexualizado; interseccionalidad. (CC BY 4.0)

Feminismo/s 34, diciembre 2019, pp. 235-263 
Representación del cuerpo, el género y la «raza» en Vida y muerte de la mulata.

Una historia que se repite

\begin{abstract}
In this essay, I will focus on and deliberate about the idea of «la mulata» derived from the hegemonic narratives in Cuban art, science, and literature of the second half of the XIXth century. Here I am interested in the images, or lack thereof, fashioning the mulatto body and what was their intention behind such signifiers. I use the interpretative keys to intersectional feminism and an interdisciplinary methodology applied to the study of this sexualizing and racializing representations of bodies. I suggest that the mulatto woman is a discursive construct of otherness (re)signifying the objectification of the black body. This cultural artifice allows for the continuation of the harm inflicted on Cuban afro-descendant women by the colonialist imagery on race, class, and gender.
\end{abstract}

Keywords: Mulatto woman; Race; Gender; Stereotype; Sexualized racism; Intersectionality.

\title{
1. INTRODUCCIÓN
}

En el presente artículo centro mi análisis en la imagen simbólica de «la mulata» cubana a finales del siglo XIX. Planteo cómo se fue tramando discursivamente este estereotipo a partir del análisis de una selección de textos de la época. Me pregunto para qué y apoyándose en qué imaginarios se construyó esta representación y qué aspectos se van repitiendo en el corpus de fuentes escogido. En este sentido, la deconstrucción de «la mulata» revela los postulados centrales del saber científico de la época. Sus características físico-morales expresan los principios del racismo científico y de la ideología de la feminidad decimonónica que, imbricados, configuran una belleza híbrida y erotizada compuesta por un cuerpo hipersexualizado y una «naturaleza» sensual que anuncia una fatalidad. «La mulata» fue una expresión del racismo de su tiempo, pero también un instrumento de racialización; en este sentido -como mecanismo- operaba de dos modos: por un lado, excluía a las mujeres que racializaba del modelo de feminidad hegemónico, legitimando su explotación económica y extorsión sexual, a la vez que reforzaba el paradigma vigente de la feminidad, al normativizar el comportamiento y la sexualidad de todas las mujeres.

La aproximación a los circuitos culturales de producción y consumo de estas representaciones -o la exclusión de ellos- problematiza su uso como

Feminismo/s 34, diciembre 2019, pp. 235-263 
Representación del cuerpo, el género y la «raza» en Vida y muerte de la mulata.

Una historia que se repite

fuentes históricas y revela la posición discursiva ambivalente de quien las produce. En diálogo con los estudios que han abordado estas cuestiones, planteo la representación de «la mulata» como una vía simbólica de inserción del cuerpo negro a la naciente nación cubana que (re)significa su cosificación. En su configuración confluyen la ideología del mestizaje, que busca la armonía de «razas», y el racismo científico, que persigue la exclusión del elemento africano barbarizante. Ambas posturas proponen la disolución del elemento africano para el despliegue del proyecto civilizatorio y se enmarcan en la configuración de discursos nacionales que desvelan ambivalencias de las elites criollas en su forma de imaginar la otredad.

La propuesta epistemológica del feminismo negro proporciona claves para interpretar el proceso de racialización poniendo atención a cómo la «raza», articuladamente con el género, la sexualidad y la clase se atraviesan al configurar dicha representación. Este enfoque subraya la importancia de la imbricación de estos marcadores de discriminación en la experiencia histórica de las mujeres afrodescendientes, e impugna a la vez la categoría homogénea de mujer. Hill Collins propone la matriz de dominación «como una herramienta conceptual» que «hace referencia a la relación general de poder en una sociedad» e indica que «cualquier matriz específica posee su particular disposición de sistemas de intersección de la opresión -raza, clase, géneroy una organización de sus dominios de poder -estructural, disciplinario, hegemónico e interpersonal». La intersección de los vectores de opresión y de privilegio crea variaciones en las formas y en la intensidad en la que las personas experimentan la opresión (299; citada en Jabardo 37).

El carácter heterogéneo de las fuentes seleccionadas revela la reiteración de un discurso que perfila las características y va tramando los relatos que crean esta imagen simbólica. El corpus textual se enmarca en el último cuarto del siglo XIX y recoge obras pictóricas de Víctor Landaluze; la versión de 1882 de la novela Cecilia Valdés o la Loma del Ángel de Cirilo Villaverde; las marquillas cigarreras sobre la vida de «la mulata» y varios estudios médico-científicos: La mulata, estudio fisiológico, social y jurídico, publicada por Eduardo Esponda en 1878 y el tratado de 1888, elaborado por Benjamín Céspedes, La prostitución en la ciudad de la Habana. La propuesta de análisis de estos textos tiene el propósito de señalar la importancia de la imbricación

Feminismo/s 34, diciembre 2019, pp. 235-263 
Representación del cuerpo, el género y la «raza» en Vida y muerte de la mulata.

Una historia que se repite

del racismo y del sexismo en la configuración de Cuba como un paraíso de mulatas, abierto a la explotación y a la penetración externa.

\subsection{Aproximaciones al estudio de la imagen simbólica de «la mulata»}

La construcción de la imagen de «la mulata» decimonónica se fundamentaba en representaciones del saber occidental mediante las cuales se establecía una relación colonizante, de escrutinio y autoridad respecto al/la Otro/a (Said 20). Jean Lamore ha subrayado la importancia de las imágenes pictóricas y los relatos de viaje -promotores de la moda del buen salvaje y de la depravación asociada a los trópicos- en la configuración del imaginario en torno a América Latina y al Caribe (Lamore 309). La vinculación entre las representaciones locales de mujeres racializadas y las miradas foráneas ha sido abordada en algunos trabajos (Bajini; Barcia) que plantean la ambivalencia de los discursos antiesclavistas con matices positivistas. En este sentido, Luis William ha estudiado las transformaciones en Cecilia Valdés hacia una posición antiesclavista, que él sostiene que solo existe en la versión de 1882. En su estudio William cartografía corrientes literarias, conecta la evolución estética con la política y revela las contradicciones discursivas que produce la difusión del racismo como dispositivo que sustituye a la esclavitud para el ordenamiento social ${ }^{1}$.

Madeline Cámara propone una deconstrucción de «la mulata» como sincretismo racial y cultural de las características de la nación cubana; señala la manipulación de los mitos yoruba, conservados en la adaptación a las colonias, y el vaciamiento del potencial subversivo del elemento africano. Para esta autora los rasgos ambivalentes del orisha Ochun sincretizan a la Virgen de la Caridad del Cobre -maternal, conciliadora y armónica- y a la mulata de rumbo -amor sexual y lascivo. Esta imagen habilita una lectura ambivalente del mestizaje: la virgen representa a la nación cubana que iguala a negros, mulatos y blancos, y «la mulata» es transgresora del orden colonial; ambas

1. Peter Wade detecta una coincidencia entre la imposición de las tesis abolicionistas y el surgimiento de teorías racistas que sancionaban la dominación sobre la población afrodescendiente a finales del s. XIX. Señala que el sistema económico esclavista era opuesto a la idea de desarrollo industrial basado en el trabajo libre y que, por lo tanto, el abolicionismo no era necesariamente un pensamiento contrario a la opresión de la población no-blanca. Esta explicación permite entender la connivencia entre abolicionismo y racismo científico (Wade 18).

Feminismo/s 34, diciembre 2019, pp. 235-263 
se asumen a la vez y revelan el deseo de imaginarse separado de la colonia y el miedo a la incorporación del otro/ de la otra. Karen Monteleone reflexiona sobre la articulación de una identidad mestiza en las nacientes repúblicas en base a la presencia del mestizaje y el incesto en tres novelas latinoamericanas. Señala la postura contradictoria del sector criollo ante el mestizaje que lo vindica como particularidad frente al imperio colonial español, pero que preocupa por la demografía racial y por la movilidad económica de la clase mulata.

Vera Kutzinski ha estudiado cómo los discursos visuales expresaban la articulación de las relaciones de poder en Cuba. A través del estudio de las marquillas cigarreras se ha preguntado sobre los recursos utilizados para plasmar un relato hegemónico sobre la sociedad cubana y la relevancia de la articulación de la raza, el género y la clase en tales expresiones. A partir del análisis de este tipo de fuentes, Tamara Kneese sostiene que «la mulata» es un producto del imperialismo español y de la esclavitud cubana en las plantaciones de tabaco y azúcar, fruto de la desigualdad socioeconómica y de la violencia sexualizada hacia las mujeres afrodescendientes por parte de los hombres blancos. Por su parte, Salvador Méndez (Feminidades racializadas; Tremendísima) analiza la proyección de las categorizaciones de los estereotipos raciales y de género en el imaginario colonial y los procesos de subjetivación femenina a partir de un estudio de la cultura visual. Alberto Gullón y Andreo García elaboran un estudio sobre la prostitución, basándose en las marquillas de tabaco como reflejo de la realidad social y económica cubana.

\subsection{Los discursos ambivalentes sobre el cuerpo de la nación en Cuba}

Durante la segunda mitad del siglo XIX se desplegaron dos procesos decisivos en Cuba: la lucha por la independencia de la metrópolis y el resquebrajamiento del sistema socioeconómico esclavista que había establecido el ordenamiento socio-racial a partir de la división de la población según el «color legal de la piel» (Stolcke). La sociedad cubana decimonónica intercalaba ideológicamente la transmisión de la pureza racial, que legitimaba la jerarquía social, y la perpetuación de las posiciones sociales hegemónicas inherentes a la pureza de «raza» (Stolcke 13,14). En la reproducción de este orden social, las mujeres blancas eran responsables de mantener el honor y la pureza racial

Feminismo/s 34, diciembre 2019, pp. 235-263 
Representación del cuerpo, el género y la «raza» en Vida y muerte de la mulata.

Una historia que se repite

familiar, mientras que las mujeres negras y mulatas establecían relaciones de concubinato con hombres blancos y reproducían unidades familiares matrifocales (117). Así, el ordenamiento jurídico fue un elemento central en la construcción racista de la sexualidad de las mujeres afrodescendientes.

Durante la primera mitad de la centuria, la generación de escritores/as del círculo criollo reformista de Domingo del Monte elaboró textos antiesclavistas en los que se posicionaban a favor de la descolonización y contra la esclavitud, por ser un sistema anacrónico de la metrópolis que frenaba el progreso (Casanova 70). La difusión del darwinismo social y de las doctrinas cientificistas contrarias al cruzamiento entre «razas» fue definiendo las posiciones nacionalistas ${ }^{2}$, que hubieron de resolver las problemáticas en torno al reclamo de incorporación de la población negra que había participado en las guerras contra la metrópolis (Pérez 323).

En un contexto de quiebre identitario se fue negociando la configuración de un relato legitimador del proyecto ideológico para imaginar a la nación cubana que se planteó, tal y como indica Pilar Pérez, en las posiciones ambivalentes respecto a las problemáticas de raza y género. La deconstrucción de «la mulata», en el marco de los enfrentamientos con la metrópolis que unieron a negros y blancos y de la construcción de los discursos sobre el cuerpo de la nación, desvela la complejidad y las contradicciones de las estrategias discursivas de las élites criollas respecto a la raza y al género. Por un lado, estas fueron resueltas mediante una estrategia discursiva universalizante que imaginaba una nación cubana sin razas y una identidad nacional sin diferencia de color de piel. Sin embargo, esta narrativa ocultaba una doble exclusión, a la vez que apuntalaba la supremacía blanca mediante el ocultamiento de la experiencia de la población negra (Pérez 327).

2. En el siglo XIX los debates en torno a la identidad nacional estuvieron atravesados por las ideas de raza. Las élites latinoamericanas adaptaron las teorías occidentales poniendo el acento en los programas de higiene social para mejorar las condiciones de vida. Algunos países, como Colombia y México, cuestionaron la degeneración del mestizaje tomándolo como un símbolo de identidad. Sin embargo, se trataba de un mestizaje que, atravesado por nociones eugenésicas sobre la prevalencia de la sangre blanca, tendía al blanqueamiento de la población; para ello se adoptaron medidas para disolver el elemento africano e indígena, como restringir la importación de mano de obra africana. Este tipo de medidas se adoptaron en diversos países de América Latina y el Caribe como Argentina, Cuba, Brasil y Venezuela (Wade 42-43).

Feminismo/s 34, diciembre 2019, pp. 235-263 


\section{LA DESCRIPCIÓN FÍSICO-MORAL DE LAS MUJERES}

En la segunda mitad del siglo XVIII disminuyeron las publicaciones con juicios negativos sobre «la mujer». Durante este periodo de expansión de la cultura de la Ilustración se persiguió implantar un modelo de familia sentimental en el que «la mujer» era valorada como madre (Provencio 43). En Cuba este arquetipo se difundió en torno a los años 40 del siglo XIX: higienistas, pedagogos, profesores, médicos y filósofos fueron configurando a «la mujer» mediante un discurso homogéneo divulgado a través de artículos costumbristas, higienistas o novelescos (42). Las investigaciones médico-científicas de la época muestran el propósito de normativizar comportamientos, sancionando las formas de vida que circunscribían el cuerpo de las mujeres a la maternidad. Este modelo se asentaba en el determinismo biológico y un concepto de reproducción que implicaba el cuidado de los hijos y la (re) producción de paradigmas culturales ${ }^{3}$ (Arcos 310). Un breve apunte sobre los instrumentos divulgativos para el disciplinamiento del cuerpo y la sexualidad de «la mujer» me permite contrastar las representaciones estereotipadas que aluden a feminidades racializadas con el modelo de feminidad normativo biológico-esencialista.

Los manuales de urbanidad decimonónicos eran dispositivos para la socialización del individuo que vigilaban los cuerpos y las conductas mediante la racionalización de todos los ámbitos de la vida. Perseguían el orden, el decoro y la moderación, a la vez que codificaban las relaciones y roles sociales por medio de una conducta social normativizada que se insertaba en la lógica de la racionalidad, tanto económica como social (Guereña 69). Producían la censura ideológica y social mediante el control de la palabra y los gestos y educaban el movimiento para la rectificación del cuerpo (Guereña 68). La conformidad con estas pautas ideológicas va a permitir a las mujeres blancas distinguirse de las demás, asumiendo el ideal de castidad. Por otra parte, el

3. La construcción de este modelo de feminidad se enmarca en el contexto de construcciones y luchas nacionalistas. En este sentido Nira Yuval Dsvis y Floya Anthias identifican diversas formas en las que las mujeres estaban implicadas en estos procesos que, además de las nombradas por Arcos, incluyen: la participación de las mujeres en las luchas nacionales, su papel como significantes de las particularidades nacionales y como agentes delimitadores del cuerpo de la nación (Mc Clintock 355).

Feminismo/s 34, diciembre 2019, pp. 235-263 
análisis médico del cuerpo de «la mujer» durante el siglo XIX indicaba que los órganos y funciones sexuales debilitaban a «la mujer», por lo que su propia naturaleza reproductiva la convertía en enferma. El cuerpo de «la mujer» se concebía como un «todo biológico-social» destinado a la reproducción. Desde este enfoque había que evitar exceder a las mujeres en el trabajo o actividades intelectuales que perjudicaran el desarrollo de los órganos reproductores y guiarlas en el camino de la maternidad (Fagula 148-149). La armonía entre debilidad física y virtud debía cultivarse en la «dedicación a la vida doméstica y evitar todo aquello que atrajera la mirada de extraños» (Villanueva 4-5, citado en Ramos 172).

Ahora bien, ¿cómo cristalizaron estos discursos en una sociedad -la cubana- estructurada socioeconómicamente en base al color legal? ¿Qué aportaba «la mulata», como representación del racismo sexualizado, a la delimitación del modelo de feminidad hegemónico? La ideología de la feminidad decimonónica interpelaba, mayoritariamente, a las mujeres criollas de las élites, si bien todas eran piezas para la reproducción del mandato colonial-patriarcal: estas guardaban el honor, y la explotación sexual y laboral se ejercía sobre los cuerpos de las otras. En este sentido, «la mulata» operaba como un artefacto ideológico que excluía simbólicamente a las mujeres que racializaba: por un lado, banalizaba la violencia y la explotación de sus cuerpos, pero también enmascaraba la naturaleza desigual del sistema colonial expulsándolas a los márgenes del modelo de feminidad. A continuación, propongo situar esta imagen entre los mecanismos de racialización y sexualización que estructuraban la sociedad cubana, como el nuevo soporte para la imagen de «la mujer» lujuriosa que expulsaba a las mujeres que racializaba de los parámetros sociales y simbólicos aceptados de la feminidad -como prostitutas, paridoras y amantes- pasando a encarnar «la tentación» para los hombres blancos.

\section{REPRESENTACIONES SEXUALIZANTES Y RACIALIZADORAS DE LOS OTROS-CUERPOS}

A continuación, analizo aspectos transversales en las representaciones de «la mulata» que se articulan en un entramado de relatos cuyos mandatos corporales y gestos sociales expresan el universo mental occidental decimonónico.

Feminismo/s 34, diciembre 2019, pp. 235-263 
Me centro en la asociación entre fisiología y carácter y en la oposición binaria entre el ángel del hogar y la femme fatale. Se trata de un primer acercamiento a un corpus de fuentes en el que subrayo el ensamblaje de discursos ideológicos -racismo y sexismo- que están presentes en la versión caribeña de la femme fatale. La imagen de «la mulata» caribeña está inscrita en el mito europeo que asociaba a «la mujer» al pecado original y que atribuía una carga simbólica negativa al color negro. Sin embargo, a lo largo de la centuria las novelas de folletín muestran cómo va adquiriendo nuevos matices que hacen más compleja la caracterización de la femme fatale y que subrayan los aspectos demoníacos de este arquetipo opuesto a personajes dulces, cuya virtud se asocia a características físicas caucásicas (Lamore 223-225).

\section{1. «Parece blanca» ${ }^{4}$}

En La mulata, estudio fisiológico jurídico y social, Eduardo Esponda plantea algunas cuestiones que se reiterarán en otras producciones culturales, como la hibridez. El autor destaca el componente africano, que asoma en el amoratamiento de los labios y las uñas o el pelo como la lana, y el aporte del padre, de ascendencia europea, que suaviza «la rigidez muscular, la dureza de la estructura y la aspereza del cutis... Todo en ella es suave, todo en ella es mórbido» (Esponda 11). Es esta mirada erotizante del hombre blanco criollo la que construye el cuerpo negro estilizado ( «la mulata»), subrayando su doble herencia: la sensualidad la aporta el elemento materno africano (barbarizante) que es civilizado en la forma por el componente blanco y paterno. La hibridez, resultante de la transgresión del orden social, se expresa para Esponda en la dicotomía entre un rostro que carece de perfecciones artísticas, no es regular ni proporcionado, y un cuerpo de Venus. Su destino está marcado por la fisiología que «inflama los deseos y arrastra la voluntad de los hombres ... derrama en torno suyo un raudal de liviandades» (Esponda 13).

El autor detecta una voluptuosidad diferente a la de las europeas, ya que estas precisan emplear fingimientos, mientras que «la mulata» de forma espontánea provoca el «delirio como una sirena de fábula» (Esponda 14), por su libidinosidad natural. Estas afirmaciones banalizan la explotación sexual

4. Recojo el nombre de la obra de teatro de Abelardo Estorino, de 1994, Parece blanca, versión infiel de una novela sobre infidelidades.

Feminismo/s 34, diciembre 2019, pp. 235-263 
Representación del cuerpo, el género y la «raza» en Vida y muerte de la mulata.

Una historia que se repite

violenta sobre las mujeres no blancas, traban los cuerpos a una imagen irresistible y a una inclinación «natural» por el desenfreno sexual, son representaciones racializadas que no escapan a su biología (Hall 428). Los referentes culturales de Esponda, expresados en la comparación entre «la mulata»y un personaje mitológico propio de la literatura clásica occidental (la sirena), refuerzan su naturaleza seductora y demoníaca. A su vez, este tipo de caracterización se enmarca en la producción de representaciones culturales del «orientalismo» que identifican aspectos del arquetipo de «la mulata» con el imaginario europeo sobre la voluptuosidad del trópico (Lamore 309).

Por su parte, Benjamín Céspedes publica en 1888 La prostitución en la ciudad de la Habana. El autor emplea la «repugnancia» como recurso descriptivo (Pérez 329) e impugna las tesis sobre la belleza de «la mulata» afirmando que reúne «la deformación física de la raza negra y lo más vulgar de la blanca» (Céspedes 174). Su discurso muestra la asimilación de las tesis contrarias a la unión interracial y una operación de delimitación de la nación criolla que excluye al cuerpo negro (Pérez 328). Asimismo, las estrategias que en la poesía subrayaban la belleza de «la mulata» ya venían enmascarando los aspectos negativos de la hibridez y le atribuían connotaciones sexuales peligrosas para los hombres:

Es un compuesto de todo, / es entre hereje y cristiana, / es como su misma piel, / entre negra y entre blanca;/ es lo mismo que la trucha/ que fluctúa entre dos aguas; / pulga que quieta atormenta, / y pacifica si salta; / pimiento que visto, gusta, / y que comido da rabia; / licor que olido conforta, / y que bebido emborracha. (Gangá; citado en Rivera 202)

Del Monte también hizo mención de su hibridez décadas atrás: «...Y la barbarie y la cultura luchan/ en su frente tostada y majestuosa, / como en la frente de Luzbel un día/ lucharon bien y mal allá en la gloria...» (Del Monte; citado en Rivera 198). Por su parte, las imágenes gráficas ilustran una belleza normativa -erotizada por la mirada del hombre blanco criollo-y una gestualidad vulgar asociada a los rasgos fenotípicos. Es el caso de La mulata de rumbo (figura 1) de De Paula-Gelabert, que revela la mirada del sujeto colonial que construye un tipo social híbrido y bastardo: «... el elemento heterogéneo que la seduce, que la conquista, que la malea y pervierte, responsable es de sus faltas, de sus vicios, de su despreocupación»(De Paula-Gelabert 32). El análisis de estas

Feminismo/s 34, diciembre 2019, pp. 235-263 
Representación del cuerpo, el género y la «raza» en Vida y muerte de la mulata.

Una historia que se repite

representaciones culturales muestra ambivalencias en los modos de mirar a «la mulata» que conforman un mismo relato.

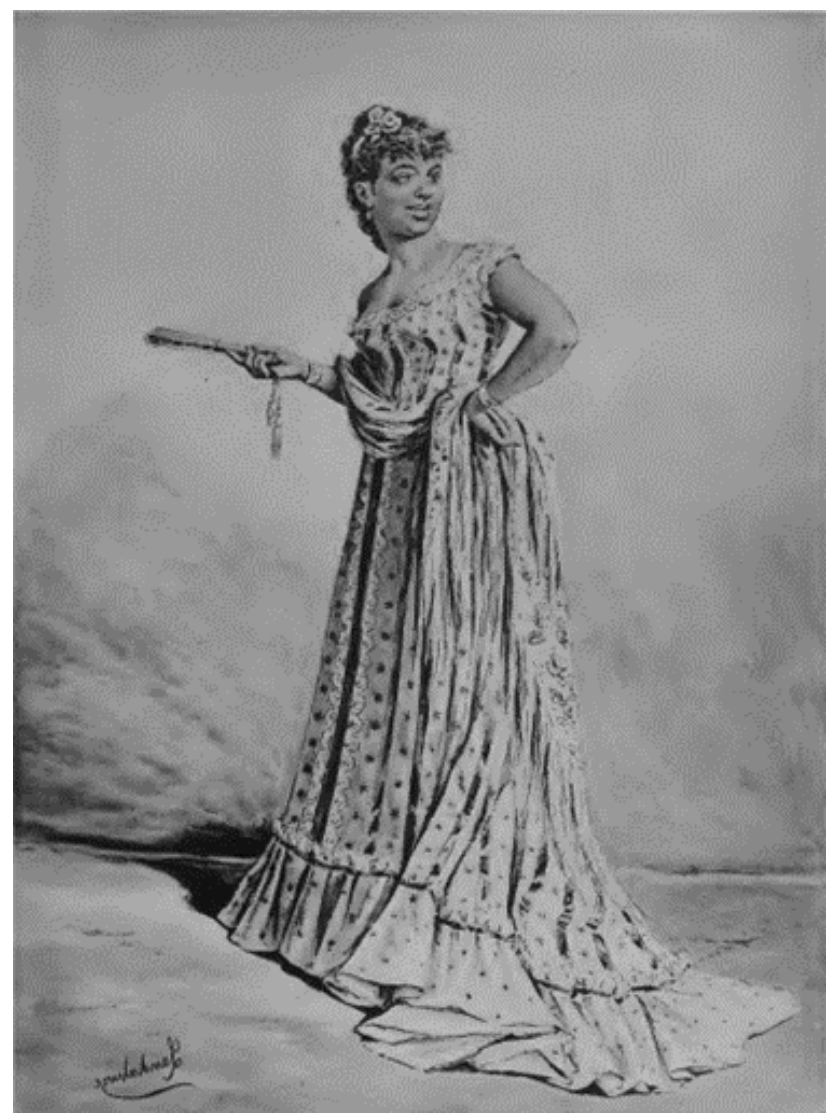

Figura 1

Las representaciones gráficas (figura 1) apuntalan la imagen literaria que exhibe un comportamiento fuera de las normas urbanidad y decoro y, en el caso de los tratados higienistas, fisiológicamente proclive a las enfermedades venéreas. En la novela de Cirilo Villaverde, la evolución estética del personaje de Cecilia Valdés, acorde al contexto del saber, se significa en la

Feminismo/s 34, diciembre 2019, pp. 235-263 
descripción física y moral de la protagonista. La versión de $1882^{5}$ muestra, al igual que los estudios de Esponda y Céspedes, la influencia de las tesis del racismo científico. En este famoso pasaje, Villaverde subraya la mancha del ascendente africano en la belleza de Cecilia «... a un ojo conocedor no podía esconderse que sus labios rojos tenían un borde o filete oscuro, y que la iluminación de su rostro terminaba en una especie de penumbra hacia el nacimiento del cabello» (Villaverde 73). La siguiente descripción muestra la conexión entre las características físicas y las morales y cómo el autor carga los rasgos fenotípicos de significado social haciendo uso de una retórica médico-descriptiva:

Sus cejas describían un arco y daban mayor sombra a los ojos negros y rasgados, los cuales eran todo movilidad y fuego. La boca la tenía chica y los labios llenos, indicando más voluptuosidad que firmeza de carácter. Las mejillas llenas y redondas y un hoyuelo en medio de la barba formaban un conjunto bello, que, para ser perfecto, sólo bastaba que la expresión fuese menos maliciosa, si no maligna. (Villaverde 73) [la cursiva es mía]

\subsection{Es el ojo del blanco ${ }^{6}$ el que crea a «la mulata»}

Seguidamente, planteo cómo «la mulata» es descrita y delimitada de manera opuesta a otros modelos femeninos. En algunos pasajes célebres de la obra de Cirilo Villaverde, el autor expresa esta representación binaria del mandato de género a través de los estereotipos del ángel del hogar y de la femme fatale. En la novela, estas representaciones son encarnadas por Isabel Ilincheta y Cecilia Valdés respectivamente. El ojo blanco, Leonardo, va delimitando las características y las hace coincidir con el papel y el espacio que corresponde a cada estereotipo:

El que se casa con Isabel está seguro de que no padecerá de... quebraderos de cabeza, aunque sea más celoso que un turco. Con las mujeres como $\mathrm{C} . .$.

5. Existen tres versiones de Cecilia Valdés: en 1839, en la revista literaria La Siempreviva, como cuento en dos partes, y ese mismo año se publica la primera versión de la novela Cecilia Valdés o la Loma del Ángel. Posteriormente, en 1879, será publicada desde Nueva York, y en la misma ciudad la versión definitiva en 1882 (Gras 374).

6. Conceptualización tomada del texto de Gosfroguel para la edición de la obra de Fanon, Piel negra, máscaras blancas de 2009, que se refiere al «privilegio ontológico y epistémico de construir al otro» (263).

Feminismo/s 34, diciembre 2019, pp. 235-263 
Representación del cuerpo, el género y la «raza» en Vida y muerte de la mulata.

Una historia que se repite

el peligro constante ... La de La Habana [Cecilia]será mi Venus citerea, la de Alquizar [Isabel] mi ángel custodio, mi monjita ursulina, mi hermana de la caridad. (Villaverde 415) [la cursiva es mía]

En el proceso de racialización operan diversos mecanismos institucionales, legales y simbólicos: «la mulata» es uno de ellos. Es un artefacto cultural útil para la naturalización de un orden social desigual que marca y traba los cuerpos en el extrarradio del modelo de feminidad normativo; para ello, se identifican rasgos fenotípicos con aspectos morales en un imaginario que construye lo femenino como humanamente inferior a lo masculino, pero que ubica lo negro por fuera de la delimitación de lo humano. Su belleza no puede separase de «parecer blanca» y, sin embargo, no lo es. En la (re) creación de este estereotipo se (re)producen imaginarios concretos -asociados a la representación europea de los trópicos- que refuerzan su naturaleza seductora y que excluyen a sectores de mujeres mediante la vinculación de atributos negativos a la «raza»:

Su belleza incomparable era, pues, una, cualidad relativa, la única quizás con la que contaba para triunfar sobre el corazón de los hombres, mas esto no constituya un título abonado para salir ella de la escena en la que había nacido ... otras menos lindas que ella y de sangre más mezclada ... aun llevaban títulos de nobleza ... disimulaban su oscuro origen ... se habían criado en la abundancia, ya se sabe que el oro purifica la sangre más turbia y cubre los mayores defectos así físicos como morales. (Villaverde 162) [la cursiva es mía]

La señora y la sirvienta de paseo (figura 2) expresa, para Méndez, la diferencia de estatus social entre dos mujeres de edad y rasgos similares. Desde su punto de vista, Landaluze sanciona el orden social colonial al representar la sumisión de una y la posibilidad de movilidad social (blanqueamiento) de la otra. Méndez interpreta cómo operan otros marcadores -nivel económico y social- en la construcción de feminidades (diversas) racializadas (Méndez, Tremendísima 326-327) que ilustran la compleja realidad social de la época que estaba estructurada, tal como como indica Stolcke, a partir del color legal.

Feminismo/s 34, diciembre 2019, pp. 235-263 
Representación del cuerpo, el género y la «raza» en Vida y muerte de la mulata.

Una historia que se repite

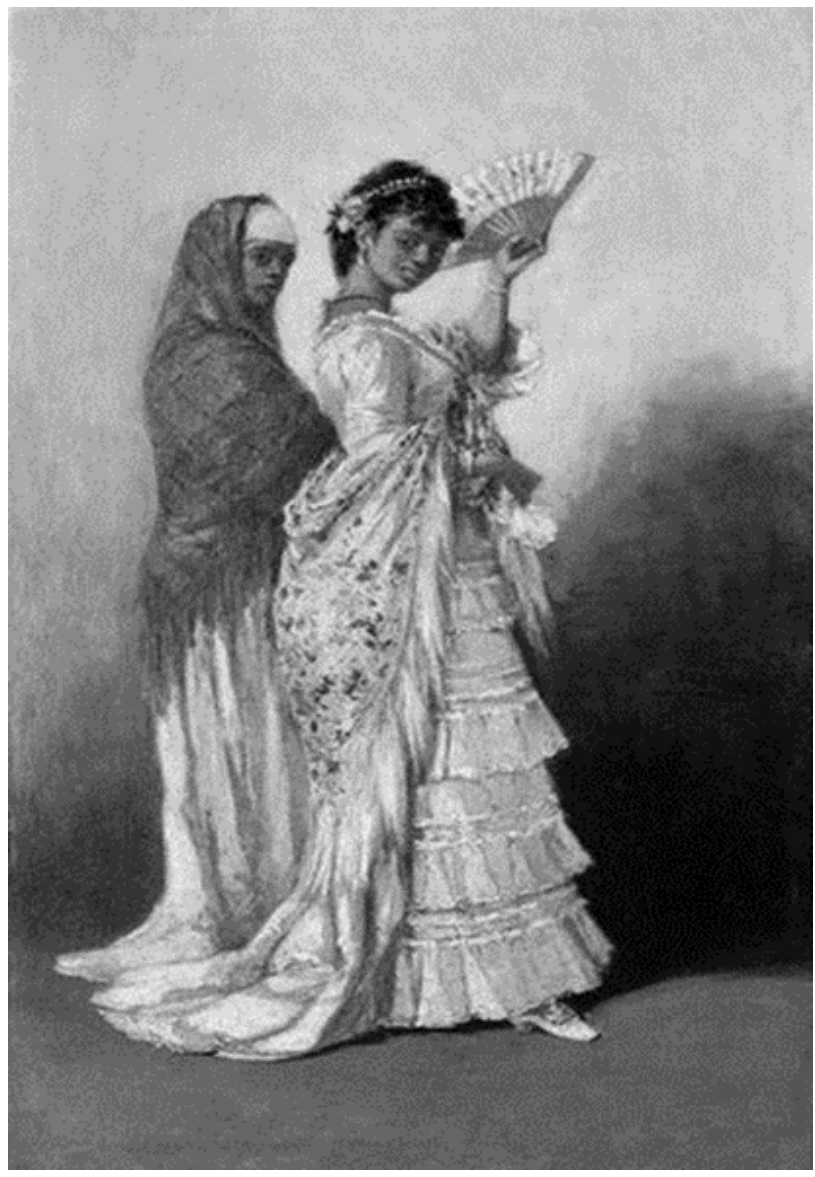

Figura 2

Es preciso matizar que «la señora», una concubina, no progresa nunca: su vida (trágica) es cíclica. La cuestión del blanqueamiento es problemática porque implicaría incorporar un modelo de feminidad del que la llamada «señora», irónicamente, está excluida por su gesto lascivo. Por otro lado, como se verá más adelante, el servicio doméstico (la sirvienta) está asociado al concubinato y al desorden en el hogar. ¿Podría esta obra ilustrar los estereotipos centrales y ambivalentes de la feminidad africana esencializada que

Feminismo/s 34, diciembre 2019, pp. 235-263 
contiene «la mulata» en el imaginario cubano? ¿Son el revés y el envés de la mulata trágica? También vale la pena matizar que las diversas feminidades que señala Méndez se dan en un grupo de mujeres ya inferiorizado, que experimenta la opresión del sexismo de manera imbricada con la racialidad. Esta diversidad entre el grupo de «las mujeres de color» ha sido sobrerrepresentada mediante una pugna por la atención del varón blanco (figura 3) para el blanqueamiento -que es en realidad el proyecto de las élites criollas atribuido a estas representaciones- y el desprecio hacia los hombres clasificados jurídicamente como no-blancos.

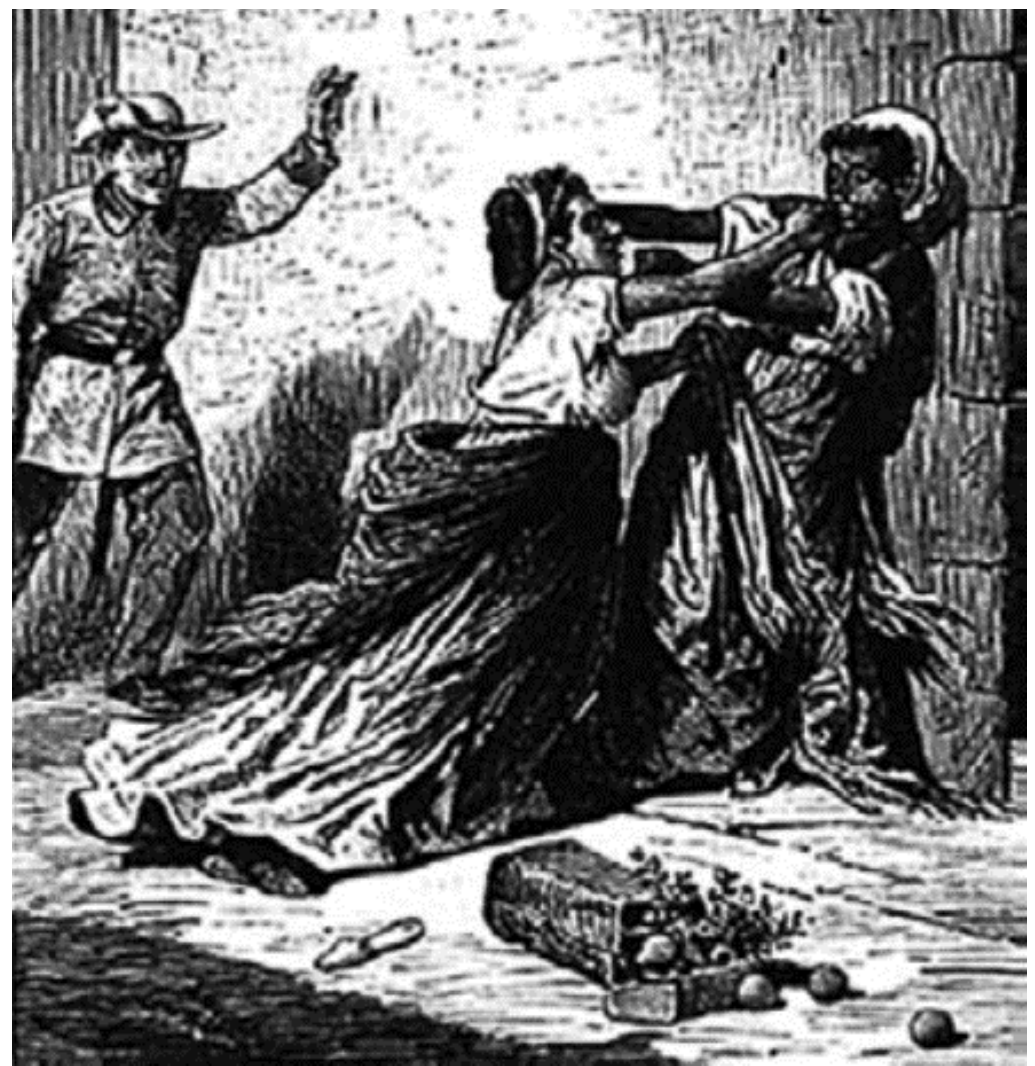

Figura 3

Feminismo/s 34, diciembre 2019, pp. 235-263 


\section{VIDA Y MUERTE DE «LA MULATA»: UNA HISTORIA QUE SE REPITE $^{7}$}

Las representaciones de «la mulata» han sido formuladas y consumidas mayoritariamente por el sector criollo, sobre todo hombres. En ellas, la vida de «la mulata» transita el espacio social en un recorrido de ida y vuelta entre la periferia y el centro; a la vez que se desclasa y atraviesa estereotipos raciales y de género. No obstante, Esponda traza un recorrido por «la vida de la mulata» cuyo final moralizante se dirige a las mujeres blancas: nadie está de luto por su muerte [de la mulata] (Esponda 21). Este mensaje, presente en las producciones de la cultura visual (figura 4) y en las historias de los personajes literarios, advierte de los peligros que conllevan las conductas impropias (para las mujeres) fuera del orden familiar y social burgués. Esta estructura trágica sitúa a «la mulata» fuera del modelo de feminidad hegemónico y, desde ahí, refuerza el mandato de género al delimitar el comportamiento de «la mujer».

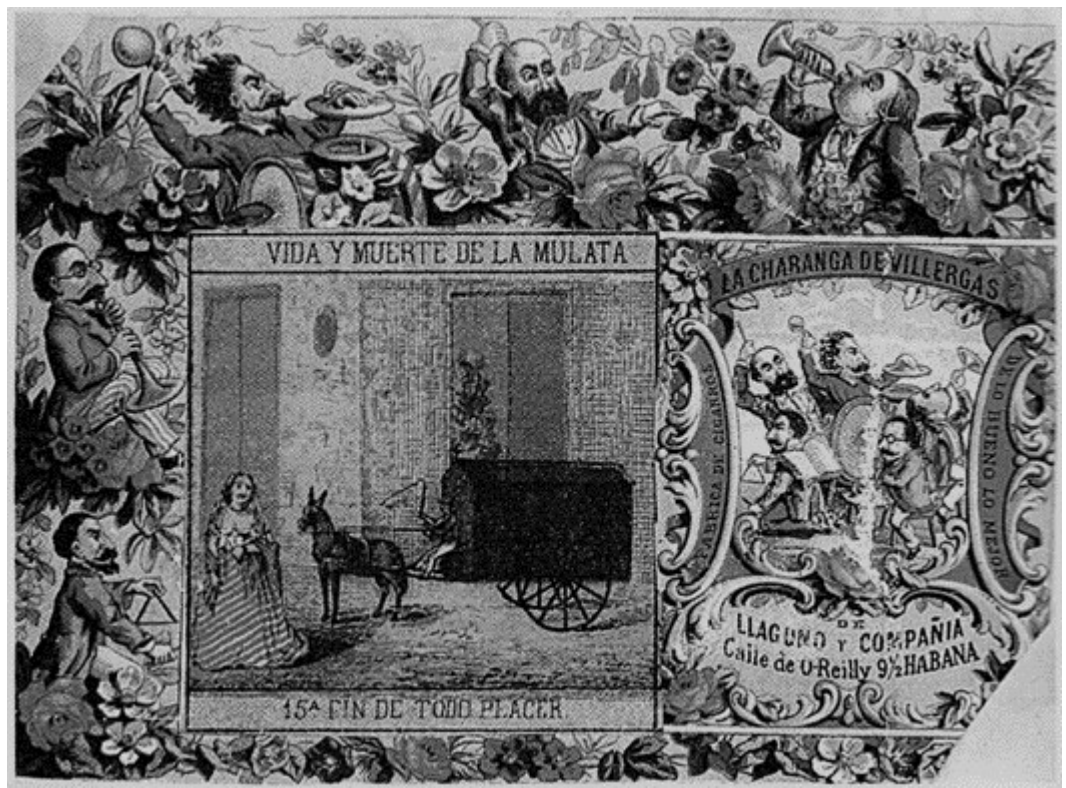

Figura 4

7. El título hace referencia a la obra de Benítez-Rojo La Isla que se repite.

Feminismo/s 34, diciembre 2019, pp. 235-263 
Representación del cuerpo, el género y la «raza» en Vida y muerte de la mulata.

Una historia que se repite

La preocupación central del autor es la degeneración de la sociedad y, al igual que Céspedes, muestra el propósito de articular modelos de masculinidad y feminidad en el marco de la construcción de los discursos sobre el cuerpo de nación acordes al proyecto civilizatorio (Pérez 329-330)

Maleado el sexo masculino, se malea el femenino de nuestra raza, y, a medida que aumenta el número de cortesanas, se aumenta la depravación... El contagio se viene difundiendo y reina en los círculos elevados, en los medios y en los inferiores una epidemia verdaderamente lamentable. (Esponda 26) [la cursiva es mía]

El problema final es el elemento africano, determinante en la vida de «la mulata», que inquieta a Esponda por la desestabilización y decadencia social:

La mulata es un ser condenado a la inmoralidad. Sus condiciones intrínsecas y su condición artificial ..., pasto de nuestra brutalidad, nos envilece al rozarnos con ella y envilece todo lo que cae bajo su mano ... Embrutece a los hombres que tienen relaciones con ellas que faltan a sus obligaciones teniendo hijos a los que no atienden (Esponda 39) [la cursiva es mía]

Sus afirmaciones ilustran la preocupación de su clase por el caos que introducen «negras y mulatas» en la familia. En primer lugar, por la asociación del concubinato al espacio doméstico y, por otra parte, por la influencia negativa sobre las mujeres que faltan a la obligación maternal de cuidar de sus criaturas $^{8}$.

... la mulata que mece nuestros hijos en la cuna, que los nutre con su leche, que los acompaña en sus juegos infantiles, que los lleva de la mano a la escuela, o en la victoria, que los tutea en la edad núbil, que se hace confidente de sus íntimos secretos y que los mima y acaricia, influye más o menos esencialmente sobre la moralidad de nuestra prole, como influye sobre su lenguaje, sobre sus modales y sobre sus ideas. (Esponda 44) [la cursiva es mía]

8. En Cuba ya desde finales del siglo XVIII e inicios del XIX se publican artículos de prensa, basados en la razón científica y moral, en los que se impulsa a las mujeres a ser las únicas que críen a sus hijos/as. Critican la costumbre de entregar a «la negra» para que lo amamantase «como si la naturaleza les escaseó los bienes que no privó a las fieras», así como para su educación, para evitar el «cuidado y trato de una negra ignorante que ni habla bien español»; también advierte del «modo de precaver en los niños la imitación de cosas ridículas o viciosas de la negra» (Papel Periódico de la Havana; citado en Provencio 57).

Feminismo/s 34, diciembre 2019, pp. 235-263 
Representación del cuerpo, el género y la «raza» en Vida y muerte de la mulata.

Una historia que se repite

La danza es un elemento central en las narrativas de la vida de la mulata; las descripciones revelan la mirada masculina erotizante que construye al cuerpo negro que baila. El baile erótico y ardiente expresa la idiosincrasia sensual mulata, así como los ritmos africanos, incomprensibles y barbarizantes para la percepción del varón blanco burgués, tornan su belleza diabólica ${ }^{9}$.

...la respiración de la mulata es anhelante, sus ojos húmedos fulguran luminosos destellos, sus mejillas se encienden como grana, despide su piel un fuego calenturiento, y sus labios se entreabren cual, si estuviera devorada por una sed insaciable, mostrando el marfil de su dentadura y bosquejando la imagen del éxtasis. (Esponda 16)

Por otro lado, el baile es un lugar de encuentro ocioso, no productivo: «la mulata dice: «vivir es gozar, gozar es bailar»» (Esponda 16). En el siglo XIX los bailes eran espacios de sociabilización que, con un carácter público o privado, reunían a la alta sociedad burguesa, sin embargo, el autor se refiere a la degradación y contaminación de las costumbres en los bailes mestizos de «razas» y clases. Sobre esta misma cuestión, Céspedes plantea que los bailes mestizos eran lugares en los que los hombres blancos se comportaban de manera contraria a una nueva masculinidad que debía poder controlar sus impulsos sexuales y contraponerse al elemento barbarizante africano, la ignorancia española y la debilidad criolla (Pérez 330-331).

El análisis de la obra de Céspedes sobre la prostitución desvela la importancia del darwinismo social como base ideológica del higienismo (Gálvez 172). El autor sostiene que el comportamiento de «las mulatas y las negras» expresa las reglas de la selección natural que eligen a los hombres blancos para sus gastos y a los negros y mulatos para sus gustos (Céspedes 172). A su vez, reproduce el mito de la potencia sexual del hombre negro y el de «las Cecilias», mujeres negras y mestizas que rechazan a los hombres de sus

9. Federici ha indicado la conexión entre la ideología de la brujería y la ideología del racismo desarrollada en la conquista del Nuevo Mundo y la trata de esclavos. Señala que el diablo es representado como un hombre negro; por un lado, el deseo sexual desbordado es característico de lo diabólico, al igual que la afición desmedida por la música y la danza, que son temas centrales en los informes de los misioneros de las Indias (273-274). Barker -citado por la autora- afirma que son caracterizaciones realizadas por los propietarios de esclavos y expone cómo la pasión por la música es tomada como muestra de la tendencia a la irracionalidad y a su naturaleza instintiva (Federici 275).

Feminismo/s 34, diciembre 2019, pp. 235-263 
comunidades para «avanzar la raza». El lenguaje médico descriptivo reitera la figura del agente patógeno que contamina los cuerpos con enfermedades venéreas y el cuerpo social por «el contagio» de comportamientos nocivos desde el servicio doméstico a las jóvenes amas a modo de «venganza de raza» (Céspedes 175-177).

Ambos autores revelan la preocupación del higienismo por controlar las enfermedades físicas y sociales que contaminan el cuerpo social (Gálvez 98) y proponen pautas de disciplinamiento de los cuerpos de las mujeres afrocubanas y migrantes mediante el despliegue de dispositivos médicos y policiales. Uno y otro vinculan el servicio doméstico a la corrupción de la conducta de los hombres y al mancillamiento de la moral de las mujeres e hijos en los hogares, a la vez que plantean la prostitución como un problema introducido por agentes externos que infecta el cuerpo social cubano. Esponda sugiere medidas de blanqueamiento cultural centradas en la educación de las mujeres «es dable a lo mínimo educarlas, instruyéndolas en lo tocante a Dios y a la humanidad... para que adquieran el hábito de la rectitud y horror a la vida desenfrenada» (45). Céspedes va más allá de los «principios de austeridad en las costumbres» (95) y asume las tesis eugenésicas, situando la naturaleza lasciva de las mujeres afrocubanas como causa del exterminio de la «raza de color» (177).

\subsection{Tramas de representación de la «maternidad mulata»}

La maternidad es central en el modelo de feminidad normativa, sin embargo, en el estereotipo de «la mulata» deviene una experiencia trágica, al nivel del alcoholismo y de la muerte, al desarrollarse por fuera de la familia normativa. La maternidad y las estrategias de control de la reproducción por parte de las mujeres esclavizadas han sido ampliamente estudiadas por las feministas afroamericanas que a este respecto han señalado que las mujeres cautivas tomaron una posición estratégica opuesta a la (re)producción de mano de obra esclavizada (Davis 35). En el caso de Cuba, Madeline Cámara afirma que durante la esclavitud se forjó el estereotipo de la sexualidad y de la maternidad africana, que estaba basado en una interpretación esencialista de las estrategias de adaptación al sistema colonial y que se incorporó a la representación de la maternidad de «la mulata» (Cámara 27).

Feminismo/s 34, diciembre 2019, pp. 235-263 
Representación del cuerpo, el género y la «raza» en Vida y muerte de la mulata.

Una historia que se repite

La trama de la maternidad está presente en Cecilia Valdés de Cirilo Villaverde. El relato comienza y termina en el hospital de Paula, donde se encuentran madre e hija: Charo, sumida en el delirio desde que dio a luz a Cecilia, y esta última, condenada por el asesinato de Leonardo, también con una hija. Estas casas de recogida junto con los hospitales eran lugares en los que desaparecían las mujeres y «las mulatas que amenazan violar los limites raciales y sociales» (González 549). Por otra parte, la estructura de esta novela reproduce la historia cíclica a la que «la mulata» no puede sustraerse y que está presente en todas las producciones culturales del estereotipo. Françoise Verges suscribe la interpretación de Fanon sobre la locura ${ }^{10}$ en relación con los contextos coloniales. Desde esta perspectiva la autora afirma que la locura, en Cecilia Valdés, es la historia de «la mulata» cubana (citada en González 549). Se trata de un devenir asociado a la experiencia de la maternidad matrifocal que transcurre a espaldas de la familia burguesa.

Cecilia Valdés plantea conflictos interraciales entre mujeres por las relaciones extramaritales y los hijos ilegítimos. Villaverde los expone a través del testimonio de la nodriza María la Regla, que amamanta a las dos hijas de Gamboa, Adela -la legítima, blanca-, Cecilia Valdés -la ilegítima, mulata- y a su propia hija, Dolores (negra): «se ponía ambas niñas a los pechos y las amamantaba con imponderable delicia» (Villaverde 301). La mujer transgrede una prohibición a pesar del consecuente castigo. Esta problemática traza un ámbito doméstico doblemente violento para negras y mulatas por la violencia sexualizada de los hombres blancos y por el maltrato ejercido por parte de sus esposas criollas que, debido a las generaciones más claras nacidas del mestizaje, podían sentir disputada su posición de mujer privilegiada «en la (re)producción de niños/as blancas/os» (Monteleone 93). En consecuencia, se producía una pugna entre «razas» con consecuencias violentas para las mujeres negras y mulatas. Este tipo de violencia por parte de las mujeres criollas no suele estar representado en las producciones culturales sobre «la mulata», sin embargo, sí está presente en las fuentes judiciales que ha investigado Verena Stolcke.

10. Fanon asocia el sufrimiento psíquico al entorno social del/de la paciente y reflexiona acerca de la enajenación producida por la esclavitud y el colonialismo. Defiende una explicación materialista que asocia los síntomas a la vida de opresión y a la dominación a la que la/el paciente es sometida/o. (Bouamama; citado en Zema 11).

Feminismo/s 34, diciembre 2019, pp. 235-263 


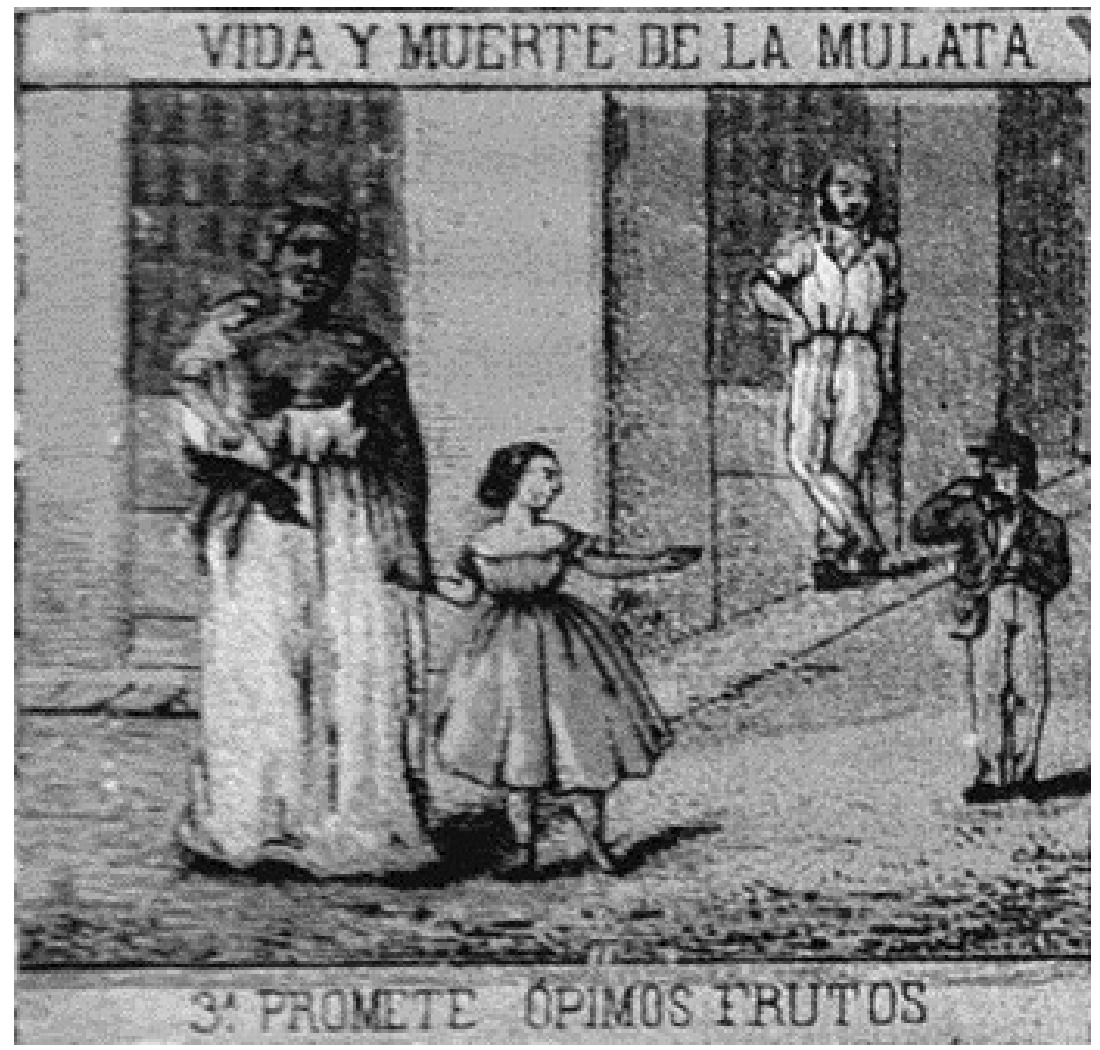

Figura 5

Andreo y Gullón abordan las marquillas de tabaco como fuentes para el análisis de la realidad de la prostitución no reglada en Cuba a la que, afirman, se dedicaban un gran número de mulatas. Señalan que la representación de «la madre mulata» (figura 5) en estas imágenes es la de una madama que inicia a su hija en artificios para cautivar al hombre blanco (Andreo y Gullón 150151). La dimensión simbólica del estigma de la prostitución interviene en el proceso de racialización, en consecuencia, las representaciones excluyen a «la mulata» del ejercicio de la maternidad. Es una operación que sitúa a las mujeres afrocubanas en los márgenes de «la feminidad», a la vez que se denigra la maternidad matrifocal y se subraya la importancia de la familia normativa.

Feminismo/s 34, diciembre 2019, pp. 235-263 
«La mulata» es un artefacto represivo que contiene un mensaje aleccionador para las mujeres-blancas, a las que recuerda las normas de sexualidad, a la vez que marca la suerte de las otras-mujeres. «La mulata» lanza un mensaje que sirve para reforzar el control de la sexualidad de todas las mujeres que no desean ser identificadas con esta representación.

\section{2. "No hay tamarindo dulce, ni mulata señorita» ${ }^{11}$}

En el contexto de difusión de las tesis cientificistas decimonónicas aumentó la producción cultural de estudios médico-científicos centrados en las problemáticas en torno a la prostitución en América Latina, el Caribe y la España peninsular. Se produjeron debates sobre la regulación de la prostitución y la necesidad de establecer medidas policiales e higiénicas para controlar la expansión de enfermedades venéreas. Las obras de Céspedes y de Esponda, pero también las marquillas cigarreras -Vida y muerte de la mulata-, plantean algunas de estas discusiones y se enmarcan en este flujo de producción cultural. El análisis de estos artefactos culturales desvela, tal y como indica Gálvez, las ideologías que subyacen a las prácticas y representaciones y su introducción desde Europa por parte de las élites intelectuales bajo el paradigma de la modernidad (90).

Céspedes sostiene que el origen del «concubinato silencioso y de la prostitución» está en la familia esclavista que, a su vez, permitió la reproducción de la mano de obra como un complemento de la trata (71). Sus tesis plantean varias cuestiones, en primer lugar, la importancia de la doble explotación de las mujeres en la (re)producción del sistema esclavista cubano -fuerza de trabajo y reproductiva- en un contexto internacional que dificultaba la importación de mano de obra esclavizada. A este respecto, las feministas afroamericanas han indicado que la violencia y la explotación sexualizada de las mujeres cautivas era la expresión del dominio económico que estaba en el centro de las relaciones «consentidas» entre hombres blancos y mujeres

11. Proverbio que surge de la valoración despectiva y los prejuicios de los hombres blancos hacia las mulatas (Stolcke 181) y que muestra que la condición de «señorita», por tanto, se desconsidera de entrada en el mismo refranero popular.

Feminismo/s 34, diciembre 2019, pp. 235-263 
Representación del cuerpo, el género y la «raza» en Vida y muerte de la mulata.

Una historia que se repite

esclavizadas y que ha sido parte del proceso de interiorización/epidermización ${ }^{12}$ de la «identidad esclava» (Hooks 20).

Por otra parte, Céspedes retrotrae las causas de la prostitución a la herencia imperial y responsabiliza de la persistencia de los problemas de higiene a la ineficiente administración española y «al carácter indisciplinado e insumiso de las negras y mulatas» (71). Sus tesis poseen un doble objetivo, el desprestigio de la herencia española y destacar la degradación que introduce el elemento africano. Así, obvia los factores socioeconómicos coyunturales -el desarrollo del capitalismo, la burocratización del Estado, las migraciones internas o externas, así como la incorporación masiva de las mujeres al trabajo asalariado (Gálvez 93) - y se vale de estereotipos negativos que se han ido configurando como resultado de la violencia sexualizada durante la esclavitud. El autor señala como causa final la inserción de costumbres salvajes desde «Nigricia» y el consecuente desorden que origina «la mulata», así como «la naturaleza voluptuosa, la ignorancia» $\mathrm{y}$ «la mente imbuida de supersticiones de las mujeres de color» (Céspedes 96-97).

Estas afirmaciones muestran la imbricación de los prejuicios de raza y clase que sancionan el mantenimiento del orden social. Desde la lógica del darwinismo social, la asociación de las mujeres afrocubanas a las enfermedades venéreas aumenta su estigmatización y las sitúa en una escala evolutiva inferior, tal y como muestran los «defectos» físicos vinculados a «la raza». La prostitución en Cuba asociada al mito sexual de «la mulata» ancla su origen en estos discursos que destacan el carácter prolífico de la prostitución de las negras, mestizas y migrantes y la hibridez como la causa de la degradación fisiológica y moral de la «raza». Es así como el mito de la promiscuidad africana se reactualiza en los discursos del racismo científico. La cuestión que me interesa subrayar es que se logra reforzar la imagen de «la mulata» lasciva combinando la sobreexposición de discursos estereotipados sobre la sexualidad africana y el enmascaramiento de la «violencia sexualizada». Al naturalizar la inclinación de las mujeres afrocubanas hacia la prostitución

12. En la edición de Piel negra máscaras blancas del 2009, Grosfoguel indica que, según Fanon: «el complejo de inferioridad psico racial es el resultado de un doble proceso: primero, económico, y subsiguientemente, de internalización (epidermización) de su inferioridad en las estructuras psíquico-corporales de los sujetos» (Fanon 263).

Feminismo/s 34, diciembre 2019, pp. 235-263 
Representación del cuerpo, el género y la «raza» en Vida y muerte de la mulata.

y el concubinato se legitima la violencia, a la vez que se dulcifican, con juegos de seducción, situaciones de extorsión sexual y desigualdad (figura 6). La versión caribeña de la femme fatale construye una armadura de significados negativos sobre las mujeres afrocubanas que encubre y banaliza una realidad social excluyente y brutal. Sin embargo, al deslizar la mirada hacia al ojo que observa se revela la ambivalencia entre el deseo de mantener el ordenamiento colonial y el temor a la africanización de Cuba.

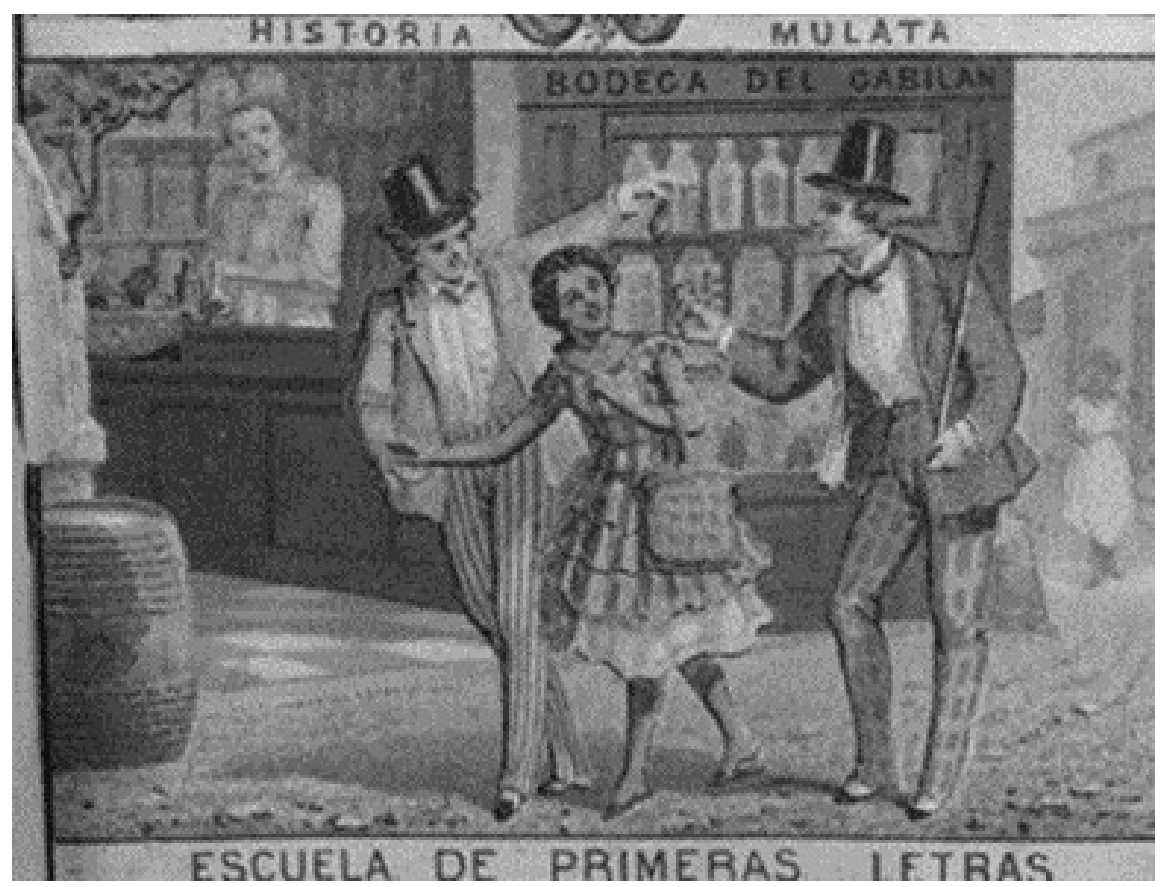

Figura 6

Feminismo/s 34, diciembre 2019, pp. 235-263 


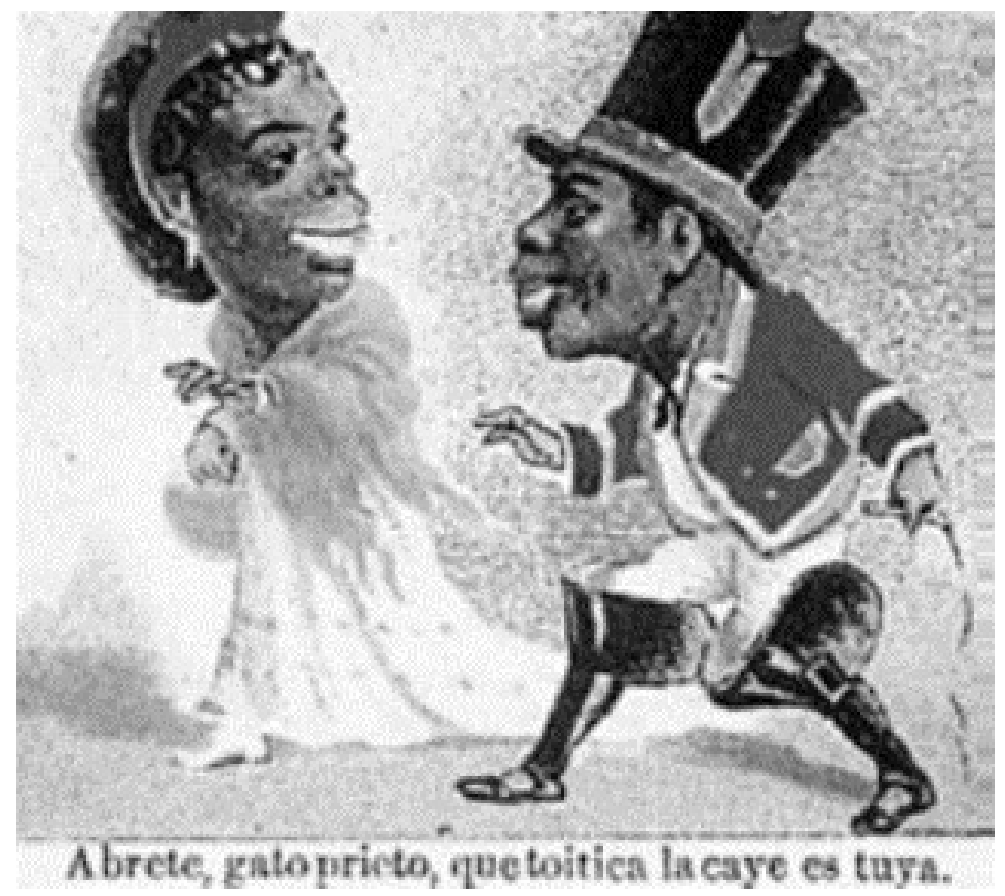

Figura 7

El estereotipo de «la mulata» insersecta desigualdades que incluyen la edad como un marcador que acentúa su vulnerabilidad. Las imágenes gráficas (figura 7) representan a mulatas envejecidas mediante la exageración del fenotipo negroide y abocadas al ejercicio de la prostitución (Méndez, Tremendísima 153). Los rasgos físicos africanos repugnantes al ojo blanco están asociados a comportamientos estereotipados sobre la sexualidad africana. El envejecimiento prematuro de «la mulata» provoca su devaluación (erótica) frente a los hombres blancos; el elemento de la edad refuerza la erótica del poder en torno a la representación porque subraya la desigualdad en la relación (figura 6). La gradación de color en las imágenes muestra una representación que ennegrece al envejecer, a la vez que se la despoja de unos atributos sexuales -otorgados por la mirada del «ojo del blanco»-indisociables de la juventud. «La mulata» que transita estereotipos no varía su posición: de joven se la

Feminismo/s 34, diciembre 2019, pp. 235-263 
asocia al concubinato, vulnerable a los avances sexuales del hombre blanco, y el paso del tiempo «la sitúa» en el entorno de la prostitución y la inseguridad de la indigencia.

\section{CONSIDERACIONES FINALES}

El estudio de este estereotipo precisa ser abordado metodológicamente a partir de un corpus teórico y documental heterogéneo e interdisciplinar. Este enfoque permite pensar a «la mulata» como una pieza del entramado discursivo que sostiene un ordenamiento socio-racial fundado sobre la explotación económica y la exclusión simbólica de los sectores sociales a los que racializa. Me refiero a que el análisis de «la mulata» junto a otros mecanismos institucionales y legales de racialización revela su sentido ideológico: es una construcción racista que perpetúa la cosificación del cuerpo no-blanco en un marco de complejas transformaciones socio políticas. El cuerpo de «la mulata» es un soporte para el discurso racista decimonónico que reactualiza antiguos prejuicios sobre la superpotencia sexual africana insertados en el relato erotizante europeo sobre los trópicos. «La mulata» contiene representaciones (foráneas) del racismo sexualizado que (re)producen la esencialización de la feminidad africana y que legitiman la condición de objeto del cuerpo negro a partir de su erotización y disponibilidad para el placer sexual de los hombres y para su explotación económica. No obstante, si se dirige la mirada a quién construye y difunde estas imágenes, y si se atiende a quién va dirigido su consumo, se revelan como dispositivos que delimitan el modelo de feminidad normativo que refuerza, desde afuera, los comportamientos adecuados al mandato de género decimonónico.

¿Es posible utilizar estas producciones culturales estereotipadas como fuentes históricas? Su origen y construcción se inserta en una larga tradición literaria europea que atraviesa el arte, la literatura y la ciencia cubanas. Los tratados higienistas y sobre la prostitución que se han analizado son textos culturales que enmascaran significados sociales con razonamientos que se pretenden neutrales, traman discursos que esconden las problemáticas socioeconómicas inherentes a la prostitución y encubren situaciones de extorsión sexual. Su confluencia con los relatos artístico-literarios emitidos por unos sectores sociales determinados, cómo estos se ponen en relación con 
las ideologías y la moral del periodo, al igual que a quién van dirigidos este tipo de artefactos culturales, van configurando espacios de legitimación para la exclusión social y simbólica. La representación de «la mulata» dulcifica las relaciones de desigualdad y, mediante el mecanismo de la racialización, sanciona el acceso ilimitado al cuerpo «abyecto» de las mujeres afrocubanas.

\section{BIBLIOGRAFÍA CITADA}

Andreo, Juan, y Alberto Gullón. « «Vida y muerte de la mulata». Crónica ilustrada de la prostitución en la Cuba del siglo XIX». Estudios Americanos de la revista del CSIC 1 (1997): 135-157.

Arcos, Carol. «Maternidad y travestismo: cuerpos de mujeres en El Mercurio Peruano de historia, literatura y noticias públicas (1791-1795)». ARENAL 15 (2009): 297-323.

Bajini, Irina. «Venus negras y vírgenes mulatas». Atti Convegni Annuali CSACA e UNISA. Ed. Giulia Nuzzo. Salerno: Oepidus edizione, 2016. 103-128.

Barcia, María del Carmen. «Sociedad imaginada: La isla de cuba en el siglo XIX». Contrastes 12 (2001): 21-42.

Benítez-Rojo, Antonio. La Isla que se repite. Barcelona: Editorial Casiopea, 1992. Cámara, Madeline. «Ochún en la cultura cubana: metáfora y metonimia en el discurso de la nación». La palabra y el hombre 125 (2002): 21-34.

Casanova, Ilia. El intersticio de la colonia, ruptura y mediación en la narrativa antiesclavista cubana. Madrid: Iberoamericana, 2002.

Céspedes, Benjamín. La prostitución en la ciudad de la Habana. La Habana: Establecimiento Tipográfico O’Reilly, 1888.

De Paula-Gelabert, Francisco. «La mulata de Rumbo». Colección de artículos, tipos y costumbres de la isla de Cuba por los mejores autores de este género. Ed. Miguel de Vila. La Habana, 1881. 33-40.

Davis, Angela. Mujeres, raza y clase. Madrid: Akal, 2004.

Esponda, Eduardo. La mulata, estudio fisiológico, social y jurídico. Madrid: Imprenta de Fontanet, 1878.

Fanon, Frank. Piel negra, máscaras blancas. Madrid: AKAL, 2009.

Fagula, Sara. «Las ilustraciones del cuerpo femenino en el tratado de ginecología de Miguel A. Fargas (1910)». Dynamis 33 (2013): 139-168.

Federici, Silvia. El Calibán y la bruja. Madrid: Traficantes de Sueños, 2004. 
Representación del cuerpo, el género y la «raza» en Vida y muerte de la mulata.

Una historia que se repite

Gálvez, Ana Carolina. «La prostitución reglamentada en Latinoamérica en la época de la modernización. Los casos de Argentina, Uruguay y Chile entre 1874-1936». Historia 1 (2017): 89-118.

González, Flora. «De lo invisible a lo espectacular en la creación de la mulata en la cultura cubana: Cecilia Valdés y María Antonia». Revista Iberoamericana 184-185 (1998): 543-557.

Gras, Dunia. «Del romanticismo al realismo, un paso tardío en la literatura hispanoamericana: Cecilia Valdés o La Loma del Ángel (1882) de Cirilo Villaverde». Del Romanticismo al Realismo. Eds. Luis Díaz, Enrique Miralles. Barcelona: Universidad de Barcelona, 1997. 371-379.

Guereña, Jean-Louis. «Urbanidad, higiene e higienismo». Áreas 20 (2000): 61-72. Hall, Stuart. Sin garantías. Trayectorias y problemáticas en estudios culturales. Eds.Eduardo Restrepo, Catherine Walsh y Víctor Vich. Instituto Pensar de estudios sociales y culturales, Universidad Javeriana, Instituto de Estudios Peruanos, Universidad Andina Simón Bolívar sede Ecuador, Envión Editores, 2010.

Hill Collins, Patricia. Black Feminist Thought. Knowledge, Consciousness, and the Politics of Empowerment. London: Routledge, 2000.

Hooks, Bell. Ain't I a Woman? Black Women and Feminism. London: South End Press, 1982.

Jabardo, Mercedes. Feminismos Negros. Una antología. Madrid: Traficantes de sueños, 2012.

Lamore, Jean. "La mulata en el discurso literario y médico francés del siglo diecinueve». La Torre (nueva época) 2 (1987): 297-318.

McClintock, Anne. Imperial leather: race, gender and sexuality in the colonial context. New York: Roudledge, 1995.

Méndez, Salvador. «Feminidades racializadas e imaginarios coloniales en el humor gráfico de Cuba en el siglo XIX». Revista científica de información y comunicación 12 (2015):135-170.

Méndez, Salvador. «Tremendísima mulata. Identidad racial, nacional y de género en la cultura visual cubana decimonónica». América: cultura visual y relaciones artísticas. Eds. Rafael López, Yolanda Guasch, y Guadalupe Romero. Granada: Universidad de Granada, 2015. 325-335.

Monteleone, Karen. «El incesto y el mestizaje en Cecilia Valdés». Revista Iberoamericana 206 (2004): 87-101.

Feminismo/s 34, diciembre 2019, pp. 235-263 
Representación del cuerpo, el género y la «raza» en Vida y muerte de la mulata.

Una historia que se repite

Pérez, Pilar. «Masculinidades en pugna: género, raza y nación en Cuba, 18781898». Mujeres, Dones, Mulleres, Emakumeak. Estudios sobre la historia de las mujeres y del género. Eds. Teresa María Ortega, Ana Aguado y Elena Hernández. Madrid: Cátedra, 2019. 323-343.

Provencio, Lucía. «La trampa discursiva del elogio a la maternidad cubana del siglo XIX». Americanía 1 (2011): 42-73.

Ramos, Johana. «Catecismos y manuales de urbanidad como recurso de acción y práctica política en Venezuela, 1830-1855». Boletín Americanista 66 (2013): 161-179.

Rivera, Aymee. Oshun Okantonú!, la imagen literaria de la mujer negra en las escritoras caribeñas. Tesis Doctoral, Universidad de Alcalá, 2012.

Said, Eduard. Orientalismo. Barcelona: Debolsillo, 2002.

Stolcke, Verena. Racismo y sexualidad en la Cuba colonial. Madrid: Alianza, 1992.

Villaverde, Cirilo. Cecilia Valdés o la Loma del Ángel. Madrid: Cátedra, 1992.

Wade, Peter. Raza y etnicidad en Latinoamérica. Quito: Ed. ABYA-YALA, 2000.

Zema, Ana Catarina. «Franz Fanon y la enajenación del negro y del blanco en el sistema colonial». Revista de estudos e pesquisas sobre as Américas 2 (2016): $1-20$. 